\title{
Resilience and Stress Management amongst Corporate Security Managers: A hybrid approach to Thematic Analysis
}

\begin{tabular}{|r|l|}
\hline Journal: & Qualitative Research in Organizations and Management \\
\hline Manuscript ID & QROM-10-2019-1837.R3 \\
\hline Manuscript Type: & Original Article \\
\hline Keywords: & $\begin{array}{l}\text { Stress, Resilience, Thematic Analysis, Stress Management, Work/life } \\
\text { balance, Job demands-control-support model }\end{array}$ \\
\hline \multicolumn{2}{|l}{} \\
\hline
\end{tabular}

\section{SCHOLARONE \\ Manuscripts}


Resilience and Managerial Stress amongst Security Managers: A hybrid approach to

\title{
thematic analysis
}

\begin{abstract}
Purpose: To examine the experience of stress by corporate security managers in the United Kingdom and how they manage it.

Design/Methodology/Approach: A qualitative approach was adopted where in-depth semi-structured one-to-one interviews with 22 male participants were conducted as the method of data collection. This was analysed using Hybrid Thematic Analysis.
\end{abstract}

Findings: Three over-arching themes were elicited, namely: "Resilience", "Synergy", and "Work/life balance". The outcome showed that stress management by security managers is moulded by an interaction of various facets, with an emphasis on "resilience" having $66 \%$ of content occurrence, a factor which complements and enriches the Job Demand-ControlSupport (JDCS) theoretical framework (Johnson and Hall, 1988).

Practical Implications: The paper argues the importance of the interaction between resilience and the dimensions of the JDCS. The research indicates the interaction is important in how practitioners can develop interventions in reducing stress in the workplace.

Social Implications: This research outcome implies that employees in managerial positions should be provided with resilience assessment and training to enhance their job effectiveness and well-being. Resilience needs to be recognised as an important trainable skill and stress management training should emphasise the enhancement of resilience. 
Originality/Value: This type of qualitative investigation on the lived experiences of stress management and how this affected one's resilience's in a high stress industry is innovative, as past research is mostly quantitative.

Keywords: Stress; Resilience; Stress Management; Job Demand-Control-Support Model; Thematic Analysis; Work/life balance 


\section{Introduction}

Stress is a detrimental reaction experienced through individuals' interaction with their psychosocial environment (World Health Organization, 2017). It negatively impacts on job performance from the psychosomatic bearing on attitude, behaviour, and decision-making (Useche, Ortiz, Cendales and Serge, 2017). The Health and Safety Executive (HSE) in the United Kingdom (UK) found that 828,000 workers suffer from work-related stress and 17.9 million workdays are lost every year (HSE, 2020). Long term exposure to stress increases symptoms of burnout, post-traumatic stress disorder (PTSD), and anxiety (Mealer et al., 2017).

\section{The Job-Demand-Control-Support Model}

This study uses the Job Demand-Control-Support (JDCS) Model (Sanne et al., 2005) as its main theoretical framework. The three domains of the JDCS are the "Demands" of the career, the "Control" exerted over the job, and "support" from peers and family in combating stress (Johnson \& Hall, 1988).

Job Demands manifest in various forms such as social, psychological, physiological, or organisational (Bakker and Demerouti, 2007), which require sustained psychological and/or physical exertion (Adenuga, 2015). The workplace may require high demands to accomplish corporate goals and achieve productive efficiency, albeit with negative consequences (Bakker et al., 2010). Moreover, Job Control is conceptualised as the individual's autonomy in conducting job tasks (Jensen, Patel, and Messersmith, 2013). This Control dimension is abstractly composed of two constructs: decision authority, referring to the individual's power to make decisions in the workplace, and skill discretion, measuring the extent to which the individual may employ their skills in the workplace (Ibrahim and Ohtsuka, 2012). 
The original Job Demand-Control model by Karasek (1979) proposed an interaction effect between demand and control. However, Johnson and Hall (1988) contended that control is not the only stress management resource available, as social support may play an important role in stress management. The Support dimension of the JDCS refers to the social support available to employees to be utilised as an intervention to stress (Viswesvaran, Sanchez and Fisher, 1999). Empirical investigations into Support demonstrate that its enhancement acts as a buffer which moderates job stress and job strain. Those individuals with greater social support provided by family, friends and colleagues, have lower mortality and stress-related health problems (Holt-Lunstad and Uchino, 2015). Regardless of workplace task pressures, if there is high enough control and support, the stress response from job demands will be perceived as lower. In comparison, if there is high demand with low control and low support great stress, strains will be experienced (Theorell \& Karasek, 1996).

Whilst the Job Demand-Control-Support model (Johnson and Hall, 1988) is a comprehensive model of stress production, it does not include relevant concepts such as resilience (Wang et al., 2017). Researchers aim to identify stressors in the workplace, so they can recommend intervention phases to minimise the tensions caused. Accumulated research has generated a capital of quantitative data about the stress process and how stressors affect employees (Mazzola, Spector, and Schonfeld, 2011). Here it is proposed that the phenomenon of resilience and stress management can be explored using qualitative approaches investigating participants' experiences.

\author{
Research Aim [relocated to appear earlier in the paper] \\ The aim of this research is to investigate the stress management by security \\ managers. The three dimensions of the JDCS (Johnson and Hall, 1988) model \\ which are the "Demands" of the career, the "Control" exerted over the job, and
}


"Support" from peers and family in combating stress will be examined. Other concepts to be examined that are related to stress include adaptation and resilience (Kinman and Grant, 2011). The aim is to explore whether participant experiences of workplace stress and stress management relate to themes of "Demand", "Control", and "Support" with the possibility of emerging themes relating to other dimensions not included in the model, such as resilience. Understanding the relevance of such elements places salience on the importance of developing stress management techniques at an individual level.

Research Question: "What stressors do security managers endure and how do they handle workplace stress?"

\section{Stress in the Security Industry}

Corporate Security Managers are responsible for the protection of an organisation's people, building, assets, environment, and products who are governed by the Private Security Industry Act 2001 (Shaftoe, 2017; White, 2015). This includes protection from burglary, trespass, terrorism, cybercrime, fraud, financial crime, and employee crime (Shaftoe, 2017). Participants in the current study were from three separate companies protecting one private organisation worth $£ 50.2$ Billion in 2018 , who are integrated into critical national infrastructure in multiple countries.

Research into the international security industry has found security guards displayed a low susceptibility to stress (Paese, Rissi, Cecconello and Costa, 2014). A strong correlation between married guards being less susceptible to stress than single guards is also identified, which can be argued to relate to the "Support" dimension on the JDCS model (Darghouth, Brody and Alegría, 2015). Foreign private security industries, such as in Brazil, require mental health checks as part of their legislation, which may be why low 
stress levels are recorded in research (Paese et al., 2014). This can be argued to correlate with why the British private security industry has twice the amount of post-traumatic stress disorder sufferers, in comparison to the British Armed Forces, where regular health checks are conducted (Dunigan and Petersohn, 2015). The British security industry does not psychologically assess its operators and managers for mental health issues and burnout as the industry in practice has major operational areas with little or no regulatory control (Button, 2011). Research shows that if demands cannot be handled, a negative strain response will be elicited which can be argued that job "demand" is high in the industry (van Doorn \& Hülsheger, 2015).

Security officers tend to have weak stress resilience which have been inferred from triple incidence rates of stress-related disorders compared to the general public (Henning et al., 2017). Salutogenic interventions can be used to improve the health and stress resilience of security officers (Johnson and Acubchuk, 2017). Some research has indicated that due to stress being an omnipresent issue within security, an intervention to improve resilience needs to be incorporated into their training programmes (Papazoglou, Collins and Chopko, 2018). However, this field lacks lived experience research in this domain, which is required to have a deeper understanding of the distress phenomenon (Spiers, Buszewicz, Chew-Graham and Riley, 2018).

\section{Building Resilience to Stress}

Resilience is a concept associated with the capability to bounce back from traumatic experiences (Angeler, Allen and Persson, 2018). It is defined as the positive role of an individual's dynamic process for adaptation to significant stress and adversity (Sarkar, 2018). Stress resilience is a complex construct which refers to an individual's capacity to handle environmental challenges, job demands, and pressure without experiencing the negative effects, and with the flexibility to internal and external stressors (Kinman and 
Grant, 2011). However, resilience as a dimension of stress management is a key feature in mitigating the experience of workplace stress (Shoss, Jiang and Probst, 2016). Moreover, stress resilience is associated with lower strain, higher job performance, and higher productivity (Smith et al., 2018).

In psychological research, stress resilience is conceptualised as a process or an inherent trait an individual possesses (Fleming, Ysasi, Harley and Bishop, 2018). It is a trainable skill to exert emotional control and self-efficacy for productive responses to workplace demands (Washington, 2017). Research indicates resilience training and interventions improve personal hardiness and subjective well-being (Smith et al., 2018). The dynamic processes which strengthen the resilience trait can be trained to handle novel and burdening stressors (Höfler, 2014). Moreover, resilience training in the form of mindfulness has shown to positively impact those with abnormal burnout psychometric scores (Goldhagen et al., 2015). Further benefits include reduction of stress and increased empathy, which allows an individual to act as a support mechanism for other employees (Kemper and Khirallah, 2015).

\section{Hybrid Thematic Analysis as an Investigative Tool}

This research uses Hybrid Thematic Analysis (HTA) (Fereday and Muir-Cochrane, 2006), which is a tool for analysing textual data and elucidating the emergence of patterns (Kerr and Beech, 2015). Data is looked at a latent level, going beyond the semantic epistemology of participants' lived experiences and interprets underlying meanings (Clarke and Braun, 2013). HTA is a blended process of inductive and deductive thematic analysis to interpret raw data (Fereday and Muir-Cochrane, 2006). This form of thematic analysis is highly suited to this project as it seeks to explore stress management using a process of deductive thematic analysis against the logical consistency of a conceptual framework (Fereday and Muir-Cochrane, 2006; Joffe, 2012). The deductive process of hybrid thematic analysis will 
use the six-steps-method of thematic analysis (Braun and Clarke, 2006). Adopting a qualitative design to this research project allows deeper insight into the nature and salience of psychometric measure constructs in a lived experience context (Shah and Corley, 2006).

\section{Method}

\section{Design}

Many stress management models have been studied from a quantitative approach (Dawson, O'Brien, \& Beehr, 2015). However, stress management theories require exploration of the rich context enabled through the use of qualitative research tools (Daymon \& Holloway, 2010). This research employed a qualitative approach to explore stress management amongst security managers, with one-to-one semi-structured interviews as the method of data collection. Corporate security managers were the chosen sample for this study due to the highly stressful context of their work role and environment.

Hybrid Thematic Analysis of the interview transcripts complemented the research question by using the JDCS (Johnson and Hall, 1988) framework to be integral to the method of deductive thematic analysis, while permitting for themes to emerge from the participant accounts using inductive coding. This was followed by a content analysis to systemically quantify the salience of each sub-theme in the emergent process (Vaismoradi, Jones, Turunen, and Snelgrove, 2016). The outcome of this study was aimed at enhancing our understanding of work stress management.

\section{Participants}

The participants of this study consisted of 22 corporate security managers from 3 organisations in the United Kingdom. Purposive sampling was used, initially recruiting six participants through contact with security organisations, then another 16 through snowball sampling. All participants were male. The age range was between 32 and 62 with a mean 
age of 45.5. The average length of employment in the security sector was 19.25 years (range: 8 - 35). Table 1 provides the participant profiles.

\section{Insert here - Table 1: Participant Profiles}

\section{Materials}

An interview schedule was constructed, where questions were grounded in literature, paying attention to the aim of the project. Most questions were derived from Sanne et al.'s (2005) questionnaire which was developed to test the JDCS framework. Interview questions included: "Do you have opportunities to learn new things at work?"; "Do you have the possibility to decide for yourself on how to carry out your work?"; "Do your coworkers understand when you're having a 'bad day'?" An audio recorder was utilised to gather the data for transcription.

\section{Procedure}

This study was approved by the Research Ethics Board of the University of XXX, following the Code of Ethics and Conduct by The British Psychological Society (2018). Participants were approached and invited to take part in this study. Face to face, one-toone, semi-structured interviews were conducted in a quiet room. The interview schedule was used to initiate and direct the exploration of participants' experiences. Prompts were also used to enhance clarification or elaboration on points made by the participants, such as "Can you provide an example of when you felt supported by your co-workers recently?" Interviews were conducted by the first author and lasted between 20 and 120 minutes with an average of 50 minutes. Script analysis was conducted on the transcripts of the audio files.

The scripts were read repeatedly by the first author to familiarise with the data. These transcribed interviews were then coded using an inductive approach. Cross-examination 
of the transcripts was conducted to look for resemblances and variances between participants' interpretative codes, leading to the emergence of predominant themes and sub-themes. Exploration was concentrated at the latent level as this method aids to classify the underlying assumptions held by participants (Braun, Clark, and Terry, 2015). Field notes were used after the thematic analysis to examine cross-over between in-interview observations and emergent interpretations. This allowed the final themes to have a datadriven emergence so that the subjective idiosyncratic interpretation is congruent with maintaining the participants' subjective point of view, permitting the identification of the context within which stress management was explored (Braun, Clarke, and Terry, 2015). The analysis and resultant themes were then reviewed by the second author to make sure that they reflect the participants' experiences.

Moreover, content analysis of the emergent themes and subthemes was conducted using a deep learning algorithm to further illustrate the pattern of their predominance in the collected data. This was done by measuring percentage occurrences of themes and subthemes (Horn et al., 2017). The algorithm was programmed to calculate the number of coded data instances that are represented within each sub-theme, in relation to all the coded data set represented in all the themes and sub-themes. This allowed the researchers to understand the prominence of sub-themes from the perspectives of the participant accounts.

\section{Findings and Interpretation}

\section{General Findings}

This research aimed to explore stress management in corporate security managers and how they handle workplace stress, identifying the latent and semantic factors within their 
accounts. Three overarching themes were identified, namely: "Resilience", "Synergy", and "Work/Life Balance". Table 2 shows the themes that emerged from the analysis with their respective sub-themes, which have been illustrated by a sample quote supporting the constituent sub-themes. Pseudonyms are used for the participants to maintain anonymity.

\section{Insert here - Table 2: Table of Themes derived from the Analysis}

\section{Insert here - Figure 1: Themes of Stress Management}

Figure 1 illustrates the breakdown of the hybrid thematic analysis with the key themes that emerged. The figure shows the three levels of analysis from theme, sub-theme, and codes, supported by the content analysis percentage figures to denote salience of themes and subthemes. The figure was created through the iteration of thematic codes, showing the grouping of similar concepts.

\section{Analysis and Interpretation}

The emergent themes and subthemes are presented and supported by participant quotes. Each theme and sub-theme also present the contents analysis percentage occurrences.

\section{Theme: Resilience (66\%)}

This theme demonstrates how participants build up resilience to workplace pressures. As they get habituated to the experienced stress, they can devise strategies and adjust how much demand they can place themselves under, and be able to recover from. This theme also captures how individuals may lose resilience through challenges at work.

\section{Sub-Theme: Dealing with Novel Stressors (25\%)}

Security Managers may come across workplace demands and stressors not previously placed upon them. Novel stressors need the creation of new stress management strategies to reduce their stress. 
Sometimes you get to that point were like everything ahh can't really phase you anymore, you've basically quite literally seen everything that can affect you. You know, but sometimes God loves throwing you a curveball making you feel as lost as the day you started (Juliet, 107-116).

Juliet reflects that over time an individual will become habituated to the daily workplace demands and stressors upon them. However, a novel stressor can still have a negative effect on an individual with good workplace resilience. The phrase "feel lost as the day you started" has implicit reasoning that novel stressors can make an individual perceive their decision latitude, skill discretion, and adaptability to become reduced significantly.

When you get something new that you've like never dealt with, hmm, like this new telecom contact, we've never dealt in this area. All the fucking tasks are steep learning curves you can't rely on anyone cause they haven't done it too, so you kinda gotta see how they're handling, if they bloody are haha (Uniform, 98-105).

This participant recounts how novel stressors add undue pressure especially when it is novel to the organisation. He talks about how when dealing with novel pressures, social support is important to reduce the demands. This implies that observing the psychosocial environment to see peer stress management strategies can aid dealing with novel stressors.

\section{Sub-Theme: Dynamic Adaptation (51\%)}

For apt stress management, individuals apply previous learning experiences to create strategies that reduce workplace demands. Enhanced experience will allow faster adaptation to stress in future. 
Haha nothing can get in my way in terms of work... by making loads of mistakes, kinda realised: solution focused approaches will let you create situations to lower your workload (Quebec, 88-91).

The interviewee explicitly discusses how intended outcomes in previous situations were not attained by poor mismanagement of demands. The experiences of mistakes have allowed Quebec to understand best possible strategies and solutions in reducing job demands and therefore stress from those demands.
AGILE has changed how I basically deal with all my projects, it's a project management philosophy where you don't have a set direction and plan. AGILE has really taught me how to move my workloads towards the goals and away from the negatives (Mike, 122-129).

Mike emphasises the importance of his project management training in AGILE. Due to the nature of AGILE which has no set plans or project roadmaps, this has allowed him to adapt to any negative situations which would have caused stress. Whilst the intended purpose of AGILE is flexible project management, the participant implicitly attributes this training for his ability to become resilient and adapt to stressors.

\section{Sub-Theme: Job Autonomy (24\%)}

Job Autonomy encompasses how freedom to deal with demands is an important notion in building resilience strategies against stress. Having job autonomy allows individuals the flexibility to tailor their training of resilience to their needs, rather than a role with poor control.

I'm at the top of my directive in the company globally. After I got my doctorate the amount of responsibility and freedom I got to do the job was insane. I can't 
can't deny my freedom allows me to deal with the challenges our company faces (Hotel, 31-40).

Hotel argues that autonomy is a key resource in enabling them to reduce his workload and organisational issues which would burden him and others. On a latent level, Hotel may believe he was given too much autonomy in their role operation. Whilst it may help with demand reduction, they may have wanted organisational support as well as autonomy. Another latent issue that emerges in this extract is that Hotel may believe he was given autonomy based on their qualification level and the responsibility after gaining a doctorate may have been too much.

\section{Theme: Synergy (25\%)}

Synergy refers to the participants' lived experience of how their interaction with the psychosocial environment and their place within can aid their workplace goals and objectives. The theme encapsulates how co-worker support and an individual's own workplace identity work together to tackle demands.

\section{Sub-Theme: Peer Support (73\%)}

The notion of peer support explores how the support of one's peers is important to shaping one's workplace identity, whilst allowing the individual know they are cared for.

I would describe the team as a really, really good team who get on very, very well, very open, very transparent, and I often ask for feedback, so they know where I am with my objectives... we all know what each other's are... so people will come to each other saying "can I take something off you?" which is great (Bravo, 273-279). 
"Can I take something off you?" has the implicit meaning that co-workers are willing to help one another. This, coupled with the strategy of allowing co-workers to know each other's objectives, fosters an environment where colleagues can support each other with their burdens. This reduces the demand on one another and fosters an apt environment to build their social identity.

\section{Sub-Theme: Job Identity (27\%)}

Job Identity refers to how security managers perceive themselves in regard to the social role they enact which helps to control their job demands within this job identity. In turn, this can boost efficiency in tackling workplace pressures.

I'm proud of what I do... yeah, I mean I'm not a copper and I'm not in the Royal Navy, no more, no. But, you know, I'm still protecting and I'm still serving. This company does good! I am helping people and protecting the company's assets (Delta, 120-124).

The role of a security manager is to protect the corporate interests. The struggles of the job tasks assigned to Delta are moderated by the belief that his work will protect and prevent danger to the people in his company. The tacit interpretation of this quote can be inferred as the culmination of job demands placed on the participant leads to an intrinsic reward achieved through his job identity.

\section{Theme: Work/Life Balance (9\%)}

This theme captures the pressures on the participants. They have implicit and explicit experiences about what the burdens of their job role demands may be. A consequence of trying to uphold the needs of the organisation has penalties of sacrificing social time. This drain from job tasks and objectives impact on participant social support. 


\title{
Sub-Theme: Overburden (52\%)
}

Participants express how their organisation allocates tasks that cause them stress. The role of the security manager is to maintain and protect the company and failure to do so has dire costs. These consequences are a burden because, not only does it affect the company financially, but it also affects the reputation the manager may hold which is integral to their job identity. The accompanying guilt further impacts security managers' self-esteem and stress levels.

\begin{abstract}
We are at risk from losing $£ 100$ million in the first year if my [Security Area] strategy is wrong, that is a lot of money to be accountable for personally, also this new addition to the company will boost law enforcement inquiries and requests by $80 \%$ which is even more work for me, also they're more technically complex..., whatever it may be is now added to the workload (Whisky, 86-91).
\end{abstract}

Whisky attributes his burden to the serious financial risk to the company if his strategy fails, assuming sole explicit liability in the event of failure. However, his strategy also increases his paperwork via law enforcement requests which if he is not able to accomplish effectively, there is a chance people might die, placing the implicit liability on himself. The project is an overload of demands as if there is an " $80 \%$ increase" in law enforcement requests that can be interpreted as the demand on him almost being doubled with no possible resources. Thus, there is a severe overburden on him. It can be assumed he may be anxious due to resource issues because Whisky is the head of a department.

It's absolutely ginormous, so you know we're just being asked to run another company with less resources due to some changes, and just losing the operational team to another department, we're taking on a new company with no security... so I'm a bit concerned about that (Sierra, 103-111). 
Sierra is here referring to a different project from Whisky's. However, the underlying subtheme is prevalent as both have been asked to take on projects which have substantial demands. They feel they may not be able to efficiently accomplish the job task demands due to factors out of their control such as budget and resources. The fact the security managers know they do not have the adequate control over company resources makes the task itself an overburden of demand and stress.

\section{Sub-Theme: Erosion of Social Support (48\%)}

The participants are consciously aware that demands have eroded their social ties. The high demand placed on participants had a negative impact on their social lives. This slowly erodes the social connections and hinders the capability to foster new ones whilst time is spent at work.

$$
\begin{aligned}
& \text { I'm estranged to my wife for } 4 \text { and a half years now, she won't divorce me, I } \\
& \text { will divorce her as soon as I can haha when the 5-year point is up... I didn't } \\
& \text { spend enough time with my family... Yeah it was selfish, I was highly driven by } \\
& \text { what I was doing... that absolutely has fundamentally destroyed my } \\
& \text { relationship with my family and I would attribute that to the burden of this job }
\end{aligned}
$$$$
\text { (Lima, 96-103). }
$$

Lima overtly mentions how his work-focussed behaviour broke down his relationships. On a semantic level, this captures how he believes the needs of his job and his choice to focus on his work meant he was not there for his family. However, on a latent level, there appears to be some reflection regarding his "selfishness". There is an underlying tone of understanding why having a good work/life balance is important to his social relationships.

Because I'm single I say there's a gap, but that gap wouldn't be filled if I wasn't working so much. A lot of the pressure is out on myself, but if I didn't 
have this free time, I'd feel the pressure here, the time I have for work is efficient to fulfil what I need to do from a workload perspective..., it has a big effect on that I'm single, which is a direct result from work (Sierra, 73-78).

Sierra implies that having a girlfriend would take up his spare time in a manner that would not allow effective accomplishment of his work tasks. He claims that having a girlfriend would increase his stress level and he avoids the possibility of that pressure by not being in a relationship. This may just be cognitive distancing as Sierra does mention that there is a "gap", and he would be "happy" having a girlfriend. Perhaps it implies that although he may be keeping up with his job pressures, he may not have good life satisfaction.

\section{Summary of the analysis}

Analysis of the transcripts allowed the emergence of three overarching themes.

Participants constructed "Resilience" by incorporating strategies to accomplish job demands and adapting to the work environment which is what the sub-theme "Dynamic Adaptation" illustrates. Participants could adapt and become resilient through the control gained from the "Authority" given to them which enhanced stress mitigation. Also, "Job Autonomy" allowed participants to create their own tailored strategies to reduce stress. "Resilience" also encompassed "Dealing with Novel Stressors" and how their strategies could positively or negatively affect previous experience in stress management.

The positive impact of "Synergy" aided the participants' ability at building "Resilience to Stress". "Synergy" is comprised of "Peer Support" which entailed how support from coworkers allowed greater efficiency at accomplishing job tasks to alleviate stress. "Job Identity" is how the participants' own perceptions about their workplace identity contributed to becoming synchronised with proficiency at dealing with their job demands. 
"Work/Life Balance" illustrated how failure at harmonising the time spent accomplishing job tasks and social commitments elicited a negative stress response. This theme had two sub-themes of "Overburden" and "Erosion of Social Support". "Overburden" refers to how increasing job demands, and tasks increased stress and the "Erosion of Social Support" led to perceptions of stress from being unable to realise social commitments.

\section{Discussion}

This research asked the question "What stresses do corporate security managers endure and how do they handle workplace stress?" This insight was attained by exploring the participants' own lived experiences and cognisant perspectives in relation to the research aim. The three emergent themes of Resilience, Synergy and Work/Life balance allow the illustration of how stress management can be influenced by proximal and distal factors.

Resilience, which accounted for $66 \%$ of participants' narratives, showed how managers adapted to stress over time and used the autonomy gained from their authority to control their stress. The "Dynamic Adaptation" illustrated adjustment to stressful circumstances to alleviate the pressure of the demands of an operational security environment. This supports stress adaptation theory regarding individual, emotional and operational modification to socioecological environmental stressors (Kinman and Grant, 2011). "Dealing with Novel Stressors" envisioned how new demands or novel stressors allows positive enhancement of resilience if trained to an adequate level. Previous research shows individuals who are capable of positively responding to novel stressors will create new strategies to manage their stress (McAllister, 2013). This study therefore proposes that resilience must take prominence in understanding stress management and should be considered to become incorporated in the JDCS model. 
"Job Autonomy" encompassed how self-sufficiency allowed control to meet demands, in line with the "Control" dimension of the JDCS (Jensen et al., 2013). This sub-theme supported the understanding that adaptability enhanced the control by participants of reducing failure dynamics (Martin et al., 2015). These unified sub-themes show how resilience is built over time by increasing participants' ability to handle environmental challenges and pressure without the negative effects (Kinman and Grant, 2011). This did not, however, support the notion by Paese et al. (2014) that married security personnel will have lower stress in relation to developing stress resilience as many participants forfeited the social support from their families. The high occurrence reference to resilience in the participants' accounts shows that learning to adapt and create resilience strategies is important for stress management. This research outcome indicates that empowering an individual with resilience reduces the dependence on external factors, such as social support. Indeed, work roles of a solitary nature, like those of corporate security managers, must depend on their own resources rather than depend on external social support.

Synergy captured how collaboration with peers allowed greater efficiency at tackling job demands. This theme accounted for $25 \%$ of saturation in the analysis. The impact on job identity of participants due to positive peer engagement allows a collective endorsement of the initiation of leader identity construction in participants (Humphreys et al., 2015). Peer support is proximal to the "support" dimension of the JDCS where individuals use social connections to mitigate their stress (Cobb, 1976). Participants showed erosion of their personal support but support was provided by the managers' peers. This demonstrates that "Support" is a complex dimension which encompasses an assortment of varying backing which can be provided (Bradley and Cartwright, 2002).

"Job Identity" is a sub-theme which did not fit into prior expectations and the theoretical framework. The sub-theme supports previous research that identity-related stress is 
mitigated by a self-perceived positive job identity (Oh and Kwon, 2010), indicating a positive relationship between self-concept and problem-solving strategies (Jaussi, Randel, and Dionne, 2007). The inference is that a positive job identity would allow greater efficiency at engaging with job demands, having the role identity transforming over time to adapt to job tasks (Moss, Gibson, and Dollarhide, 2014).

Work/Life balance demonstrated that an equilibrium between work and social life must be attained and had the least occurrence of only $9 \%$. This is perhaps unsurprising with this term becoming somewhat overused, and the spill-over effect between the two becoming more and more common. The sub-themes were "Overburden" and "Erosion of Social Support". Overburden refers to the demands of the job and in participant accounts this referred to the overload of demands placed on them. This sub-theme compliments the theoretical quantitative (Workload and time pressure) and qualitative (Physical and emotional strain) features of “demand” (Häusser et al., 2010). Moreover, "Overburden” demonstrates the demand aspect of the JDCS in terms of the costs engaging in the security job in its various manifestations such as social, psychological, physiological, and organisational costs (Adenuga, 2015; Bakker and Demerouti, 2007). "Erosion of Social Support" demonstrated how time pressures and demand overload eroded the social support available to participants. The erosion of social support illustrates how lower support can contribute to stress (Viswesvaran et al., 1999) as "support" is seen as an interventionary variable in buffering stress (Holt-Lunstad and Uchino, 2015). The analysis of the current study has found that "support" can be broken down into two facets as this sub-theme illustrated how lower family/friends support increased stress. However, there was evidence of peer support which mitigated for stress.

\section{Conclusion, contribution and future direction}


This study shows that in examining the experience of stress management, attention needs to move to the centrality of resilience. The shift on focus on a trainable skill such as resilience will allow overall stress reduction and enhance stress reduction dimensions of the JDCS. This is particularly important in solitary roles such as security management. Previous research has claimed the three components of the JDCS model are narrative of workplace stress qualities (Sanne, Mykletun, Dahl, Moen, and Tell, 2005). However, this research can enhance the theoretical understanding of stress qualities and is generative of future academic work into the field of stress management. This qualitative study uncovered that even though it has been argued that stress resilience (Kinman and Grant, 2011) and stress adaptability are two different dimensions (MacLarnon et al., 2015), stress adaptability over time leads to greater stress resilience.

Integrating the dimension of resilience (Kinman and Grant, 2011) into the JDCS has been shown in this study to be a component of stress mitigation. Past research has found there is weak association and interaction effect between control and support as dimensions in buffering stress (Hausser et al., 2010). Integrating resilience as a dimension may be the missing link on how control and support can interact in buffering stress, as qualitative studies show control enhances resilience (Paese et al., 2014).

This study recommends the psychometric assessment of resilience in individuals to examine a manager's suitability as a key skill development area. The assessment also encourages adoption of training in improving resilience and creating a culture where personal emotional development is stimulated. Corporations are heavily investing in staff well-being and lowering their stress to stop its deleterious consequences (Dollar and Neser, 2013). More cost-effective methods corporations may undertake is screening for mental health issues and how resilient potential staff can be. For instance, the Brazilian legislative 
model is more risk centric (Paese et al., 2014), thus minimising the employment of staff who may succumb to the pressure of job demands.

This study used a qualitative approach to examine stress management. The deeper insight gained from a qualitative framework aids in defining what measures are employed in quantitative research (Shah and Corley, 2006). The applied analysis gained a deeper insight in identifying and analysing participant accounts and elucidating qualitative patterns (Kerr and Beech, 2015). The research framework preserved the rich description of participants while preventing theme contamination from the inductive element. A limitation was the usage of an all-male sample within the same industry. Whilst this study may be extrapolated to proximal industries such as law enforcement and military, it may not be applicable to more saturated industries.

The results of this research provide a window into how security managers employ stress management to mitigate for the workplace stressors they experience. Different themes may be produced if this research was to be conducted in another context. Future research for this area can also possibly include the integration of "Resilience" (R) into the JDCS to improve the stress management model by evolving to the "JDCSR" model of stress management.

Whilst the JDCS describes workplace qualities in stress and stress management through the three dimensions, this research shows how "resilience" is crucial in stress management when analysing the distal and proximal factors in corporate security managers. Thus, stress management training amongst organisational leaders should include and prioritise the enhancement of resilience. Work/Life Balance and Support is seen as important in previous research (Bradley and Cartwright, 2002). However, ultimately it seems from this 
research that resilience is more effective to strengthen the skills of the individuals, particularly in solitary roles such as corporate security managers. 


\section{References}

Adenuga, O.A. (2015), “Impact of Occupational Stress on Job Satisfaction and Mental Health of First Bank Employees: Implication for Personnel Psychologists”, Science, Vol. 1 No.1, pp. 15-21.

Angeler, D.G., Allen, C.R. and Persson, M.L. (2018), "Resilience concepts in psychiatry demonstrated with bipolar disorder", International journal of bipolar disorders, Vol. 6 No. 1, pp. 2-4.

Bakker, A. B., and Demerouti, E. (2007), “The job demands-resources model: State of the art”, Journal of Managerial Psychology, Vol. 22 No. 3, pp. 309-328.

Bakker, A. B., Veldhoven, M., and Xanthopoulou, D. (2010), "Beyond the DemandControl model: Thriving on high job demands and resources", Journal of Personnel Psychology, Vol. 9 No. 3, pp. 3-16.

Bradley, J. R., and Cartwright, S. (2002), "Social Support, Job Stress, Health, and Job Satisfaction Among Nurses in the United Kingdom", International Journal of Stress Management, Vol. 9 No. 3, pp. 163-182.

Braun, V., \& Clarke, V. (2006), "Using Thematic Analysis in Psychology", Qualitative research in psychology, Vol. 3 No. 2, pp. 77-101.

Braun, V., Clarke, V., and Terry, G. (2015), "Thematic analysis", Qualitative Research in Clinical and Health Psychology, Vol. 95 No. 1, pp. 113-116.

Button, M. (2011), “The Private Security Industry Act 2001 and the security management gap in the United Kingdom”, Security Journal, Vol. 24 No. 2, pp. 118-132. 
Clarke, V., and Braun, V. (2013), “Teaching Thematic Analysis: Overcoming Challenges and Developing Strategies for Effective Learning", The Psychologist, Vol. 26 No. 2, pp. 120-123.

Cobb, S. (1976), "Social Support as a Moderator of Life Stress”, Psychosomatic Medicine, Vol. 38 No. 5, pp. 300-314.

Darghouth, S., Brody, L., \& Alegría, M. (2015), “Does Marriage matter? Marital status, Family Processes, and Psychological Distress among Latino Men and Women”, Hispanic Journal of Behavioral Sciences, Vol. 37 No. 4, pp. 482-502.

Dawson, K.M., O'Brien, K.E. and Beehr, T.A. (2015), “The role of hindrance stressors in the job demand-control-support model of occupational stress: A proposed theory revision”, Journal of Organizational Behavior, Vol. 37 No. 3, pp. 397-415.

Daymon, C. and Holloway, I. (2010). Qualitative research methods in public relations and marketing communications, London, Routledge.

Dollar, M. F., \& Neser, D. Y. (2013). "Worker health is good for the economy: Union density and psychosocial safety climate as determinants of country differences in worker health and productivity in 31 European countries", Social Science \& Medicine, Vol, 92 No. $1,114-123$.

Dunigan, M., \& Petersohn, U. (Eds.) (2015), The Markets for Force: Privatization of Security Across World Regions, University of Pennsylvania Press, Philadelphia, Pennsylvania.

Fereday, J., and Muir-Cochrane, E. (2006), “Demonstrating Rigor Using Thematic Analysis: A Hybrid Approach of Inductive and Deductive Coding and Theme Development", International Journal of Qualitative Methods, Vol. 5 No. 1, pp. 80-92. 
Fleming, A. R., Ysasi, N. A., Harley, D. A., and Bishop, M. L. (2018), Disability and Vocational Rehabilitation in Rural Settings, Springer International Publishing, New York, NY.

Goldhagen, B. E., Kingsolver, K., Stinnett, S. S., and Rosdahl, J. A. (2015), “Stress and burnout in residents: impact of mindfulness-based resilience training", Advances in medical education and practice, Vol. 6 No. 1, pp. 525-532.

Häusser, J. A., Mojzisch, A., Niesel, M., \& Schulz-Hardt, S. (2010), “Ten Years On: A Review of Recent Research on the Job Demand-Control (-Support) Model and Psychological Well-Being”, Work \& Stress, Vol. 24 No. 1, pp. 1-35.

Health \& Safety Executive (2020), "Work related stress depression or anxiety statistics in Great Britain, 2020”, available at: http://www.hse.gov.uk/statistics/causdis/stress.pdf (accessed 3 December 2020).

Henning, R., Zweber, Z., Bizarro, A., Bauerle, T., Tubbs, D., and Reeves, D. (2017), “The Application of Salutogenesis to Correctional Officers in Corrections Settings", in: Mittelmark M. et al. (Ed.), The Handbook of Salutogenesis, Springer, Cham, CH, available at: https://www.ncbi.nlm.nih.gov/books/NBK435857/ (accessed 13 February 2019).

Höfler, M. (2014), “Psychological Resilience Building in Disaster Risk Reduction:

Contributions from Adult Education”, International Journal of Disaster Risk Science, Vol. 5 No. 1, pp. 33-40.

Holt-Lunstad, J., and Uchino, B. (2015), “Social Support and Health”, in Glanz, K., Rimer, B. and Viswanath, K. (Eds.), Health Behavior: Theory, Research and Practice, JosseyBass/Wiley, Hoboken, NJ. 
Horn, F., Arras, L., Montavon, G., Müller, K. R., and Samek, W. (2017), “Exploring Text

Datasets by Visualizing Relevant Words", arXiv preprint, arXiv:1707.05261, University of Cornell archives, Ithaca, NY.

Humphreys, J. A., Novicevic, M. M., Smothers, J., Haden, S. S. P., Hayek, M., Williams, W. A., and Oyler, S. (2015), "The Collective Endorsement of James Meredith: Initiating a Leader Identity Construction Process”, Human Relations, Vol. 68 No. 9, pp. 1389-1413.

Ibrahim, R. Z. A. R., and Ohtsuka, K. (2012), "Review of the Job Demand-Control and Job Demand-Control-Support Models: Elusive Moderating Predictor Effects and Cultural Implications", Southeast Asia Psychology Journal, Vol. 3 No. 1, pp. 12-14.

Jaussi, K. S., Randel, A. E., and Dionne, S. D. (2007), “I Am, I Think I Can, and I Do: The Role of Personal Identity, Self-Efficacy, and Cross-Application of Experiences in Creativity at Work", Creativity Research Journal, Vol. 19 No. 3, pp. 247-258.

Jensen, J. M., Patel, P. C., and Messersmith, J. G. (2013), "High-Performance Work Systems and Job Control Consequences for Anxiety, Role Overload, and Turnover Intentions", Journal of Management, Vol. 39 No. 6, pp.1699-1724.

Joffe, H. (2012), “Thematic Analysis” in Harper, D. and Thompson, A. (Eds.), Qualitative Research Methods in Mental Health and Psychotherapy: A Guide for Students and Practitioners, Blackwell, Chichester, pp. 209-223.

Johnson, B., and Acabchuk, R. (2017), "What are the Keys to a Longer, Happier Life? Answers from Five Decades of Health Psychology Research”. Social Science and Medicine, Vol. 196 No. 2, pp. 218-226. 
Johnson, J.V. and Hall, E.M. (1988), “Job Strain, Work Place Social Support, and

Cardiovascular Disease: A Cross-Sectional Study of a Random Sample of the Swedish

Working Population”, American Journal of Public Health, Vol. 78 No. 10, pp. 1336-1342.

Karasek, R. A. (1979), “Job demands, job decision latitude, and mental strain: Implications for job redesign", Administrative Science Quarterly, Vol. 24 No. 1, pp. 285-308.

Kemper, K. J., and Khirallah, M. (2015), “Acute Effects of Online Mind-Body Skills

Training on Resilience, Mindfulness, and Empathy", Journal of Evidence-Based

Complementary and Alternative Medicine, Vol. 20 No. 4, pp. 247-253.

Kerr, K., and Beech, A.R. (2015), “A Thematic Analysis of the Motivation Behind Sexual Homicide from the Perspective of the Killer", Journal of Interpersonal Violence, Vol. 31 No. 20, pp. 3464-3489.

Kinman, G., and Grant, L. (2011), "Exploring Stress Resilience in Trainee Social Workers: The Role of Emotional and Social Competencies", British Journal of Social Work, Vol. 41 No. 2, pp. 261-275.

MacLarnon, A. M., Sommer, V., Goffe, A. S., Higham, J.P., Lodge, E., Tkaczynski, P., and Ross, C. (2015), “Assessing Adaptability and Reactive Scope: Introducing a New Measure and Illustrating its Use Through a case Study of Environmental Stress in ForestLiving Baboons", General and Comparative Endocrinology, Vol. 215 No. 1, pp. 10-24.

Martin, A. J., Nejad, H., Colmar, S., Liem, G. A. D., and Collie, R. J. (2015), “The Role of Adaptability in Promoting Control and Reducing Failure Dynamics: A Mediation Model", Learning and Individual Differences, Vol. 38 No. 1, pp. 36-43.

Mazzola, J. J., Schonfeld, I. S., and Spector, P. E. (2011), "What qualitative research has taught us about occupational stress", Stress and Health, Vol. 27 No. 2, pp. 93-110. 
McAllister, M. (2013), “Resilience: A Personal Attribute, Social Process and Key

Professional Resource for the Enhancement of the Nursing Role", Professioni infermieristiche, Vol. 66 No. 1, pp.14-18.

Mealer, M., Hodapp, R., Conrad, D., Dimidjian, S., Rothbaum, B., and Moss, M. (2017), "Designing a Resilience Program for Critical Care Nurses", The American Association of Critical-Care Nurses Journal of Advanced Critical Care, Vol. 28 No. 4, pp. 359-365.

Moss, J. M., Gibson, D. M., \& Dollarhide, C. T. (2014). “Professional identity development: A grounded theory of transformational tasks of counsellors", Journal of Counselling \& Development, Vol. 92 No. 1, 3-12.

Oh, J., and Kwon, J. (2010), “Job Identity and Job Stress on Elementary School Health Teachers", Journal of Korean Academy of Community Health Nursing, Vol. 21 No. 3, pp. 341-350.

Paese, A., Rissi, V., Cecconello, W. C., \& Costa, C. (2014), “Stress among Brazilian Security Guards: Analysis of Vulnerability Factors”, International Journal of Psychology and Behavioral Sciences, Vol. 4 No. 4, pp. 113-120.

Papazoglou, K., Collins, P., and Chopko, B. (2018), “Mindfulness and Officer Health, Job Performance, and Well-Being”, FBI Law Enforcement Bulletin, 18 October, pp. 1-6.

Sanne, B., Mykletun, A., Dahl, A., Moen, B., and Tell, G. (2005), “Testing the Job Demand-Control-Support Model with Anxiety and Depression as Outcomes: The Hordaland Health Study", Occupational Medicine, Vol. 55 No. 6, pp. 463-473.

Sarkar, M. (2018), "Psychological Resilience: Definitional Advancement and Research Developments in Elite Sport", International Journal of Stress Prevention and Wellbeing, Vol. 1 No. 3, pp. 1-4. 
Shaftoe, H. (2017). Crime Prevention: Facts, fallacies and the future. Macmillan International Higher Education.

Shah, S. K., and Corley, K. G. (2006), "Building Better Theory by Bridging the Quantitative-Qualitative Divide", Journal of Management Studies, Vol. 43 No. 8, pp. $1821-1835$.

Shoss, M., Jiang, L., and Probst, T. (2016), "Bending Without Breaking: A Two-Study Examination of Employee Resilience in the Face of Job Insecurity”, Journal of Occupational Health Psychology, Vol. 23 No. 1, pp. 112-126.

Smith, B., Shatté, A., Perlman, A., Siers, M., and Lynch, W. (2018), “Improvements in Resilience, Stress, and Somatic Symptoms Following Online Resilience Training: A Dose-response Effect", Journal of Occupational and Environmental Medicine, Vol. 60 No. 1, pp. 1-5.

Spiers, J., Buszewicz, M., Chew-Graham, C., and Riley, R. (2018), “The Experiences of General Practitioner Partners Living with Distress: An Interpretative Phenomenological Analysis", Journal of Health Psychology, available at: https://journals.sagepub.com/doi/pdf/10.1177/1359105318758860 (accessed 26 September 2018).

The British Psychological Society (2018). Code of Ethics and Conduct. Available at: https://www.bps.org.uk/sites/bps.org.uk/files/Policy\%20\%20Files/BPS\%20Code\%20of\%20Ethics\%20and\%20Conduct $\% 20 \% 28$ Updated $\% 20 J u l y$ $\% 202018 \% 29 . p d f$ 
Theorell, T., \& Karasek, R. A. (1996), "Current issues relating to psychosocial job strain and cardiovascular disease research", Journal of Occupational Health Psychology, Vol. 1 No. 2, pp. 9-13.

Vaismoradi, M., Jones, J., Turunen, H., and Snelgrove, S. (2016), “Theme Development in Qualitative Content Analysis and Thematic Analysis", Journal of Nursing Education and Practice, Vol. 6 No. 5, pp. 100-110.

van Doorn, R. R., \& Hülsheger, U. R., (2015), “What makes employees resilient to job demands? The role of core self-evaluations in the relationship between job demands and strain reactions", European Journal of Work and Organizational Psychology, Vol. 24 No. 1, pp. 76-87.

Viswesvaran, C., Sanchez, J. I., and Fisher, J. (1999), "The Role of Social Support in the Process of Work Stress: A Meta-Analysis", Journal of Vocational Behaviour, Vol. 54 No. 2, pp. 314-334.

Wang, L., Wang, Y., Chen, Y., Dong, D., and Dong, W. (2017), “Stressor Load and Stress Resilience: A New Perspective for Occupational Stress", in International Conference on Engineering Psychology and Cognitive Ergonomics in Vancouver, Canada, 2017, Springer, Switzerland, pp. 232-243.

Washington, J. (2017), “The Correlation Between Emotional Intelligence and Employee Engagement Within the Human Services Industry" (Unpublished doctoral dissertation). University of Phoenix, Phoenix, Arizona.

World Health Organization. (2017), Work, Organization, and Stress, World Health Organisation: Institute of Work, Health, and Organizations, Nottingham, UK. 
White, A. (2015). The impact of the private security industry act 2001. Security Journal, Vol. 28 No. 4, pp. 425-442. 
Table 1: Participant Profiles

\begin{tabular}{|c|c|c|c|c|c|c|}
\hline Name & Age & $\begin{array}{l}\text { Years in } \\
\text { Security }\end{array}$ & $\begin{array}{l}\text { Years at } \\
\text { Company }\end{array}$ & Job Level & $\begin{array}{l}\text { Marital } \\
\text { Status }\end{array}$ & $\begin{array}{l}\text { No. of } \\
\text { Children }\end{array}$ \\
\hline Alpha & 43 & 20 & 11 & $\begin{array}{l}\text { Head of } \\
\text { Department }\end{array}$ & Married & 2 \\
\hline Bravo & 51 & 30 & 4 & $\begin{array}{l}\text { Department } \\
\text { Manager }\end{array}$ & Single & 1 \\
\hline Charlie & 47 & 30 & 11 & $\begin{array}{l}\text { Head of } \\
\text { Department }\end{array}$ & Married & 2 \\
\hline Delta & 44 & 15 & 2 & $\begin{array}{l}\text { National } \\
\text { Manager }\end{array}$ & Married & 4 \\
\hline Echo & 47 & 20 & 9.5 & $\begin{array}{l}\text { Head of } \\
\text { Department }\end{array}$ & Estranged & 2 \\
\hline Foxtrot & 32 & 11 & 3 & $\begin{array}{l}\text { Team } \\
\text { Manager }\end{array}$ & Married & 0 \\
\hline Golf & 41 & 8 & 1 & $\begin{array}{l}\text { Team } \\
\text { Manager }\end{array}$ & Widow & 2 \\
\hline Hotel & 62 & 35 & 16 & $\begin{array}{l}\text { Global } \\
\text { Director }\end{array}$ & Married & 5 \\
\hline India & 39 & 15 & 1 & $\begin{array}{l}\text { National } \\
\text { Manager }\end{array}$ & Married & 1 \\
\hline Juliet & 43 & 20 & 7 & $\begin{array}{l}\text { Continent } \\
\text { Manager }\end{array}$ & Partnered & 0 \\
\hline Kilo & 35 & 19 & 4 & $\begin{array}{l}\text { Team } \\
\text { Manager }\end{array}$ & Single & 0 \\
\hline Lima & 53 & 22 & 3 & $\begin{array}{l}\text { Head of } \\
\text { Department }\end{array}$ & Married & 3 \\
\hline Mike & 38 & 10 & 1 & $\begin{array}{l}\text { National } \\
\text { Manager }\end{array}$ & Married & 2 \\
\hline November & 59 & 31 & 13 & $\begin{array}{l}\text { National } \\
\text { Director }\end{array}$ & Single & 6 \\
\hline Oscar & 49 & 21 & 7 & $\begin{array}{l}\text { Head of } \\
\text { Department }\end{array}$ & Married & 2 \\
\hline Papa & 46 & 13 & 3 & Director & Married & 0 \\
\hline Quebec & 47 & 10.5 & 10.5 & $\begin{array}{l}\text { Head of } \\
\text { Department }\end{array}$ & Single & 0 \\
\hline Romeo & 39 & 9 & 6 & $\begin{array}{l}\text { Team } \\
\text { Manager }\end{array}$ & Married & 3 \\
\hline Sierra & 40 & 16 & 5 & Director & Married & 4 \\
\hline Tango & 53 & 20 & 9 & $\begin{array}{l}\text { Head of } \\
\text { Department }\end{array}$ & Widow & 0 \\
\hline Uniform & 50 & 28 & 6 & $\begin{array}{l}\text { National } \\
\text { Manager }\end{array}$ & Married & 2 \\
\hline Whisky & 43 & 20 & 11 & $\begin{array}{l}\text { Head of } \\
\text { Department }\end{array}$ & Married & 2 \\
\hline
\end{tabular}


Table 2: Table of Themes derived from the Analysis

\begin{tabular}{|c|c|c|}
\hline Theme & Sub-Theme & Illustration Quote \\
\hline \multirow[t]{3}{*}{$\begin{array}{c}\text { Resilience } \\
\text { (66\%) }\end{array}$} & $\begin{array}{c}\text { Dynamic Adaptation (51\%) } \\
\text { Type: Semantic }\end{array}$ & $\begin{array}{c}\text { "Haha nothing can get in my way in terms of work... by } \\
\text { making loads of mistakes, kinda realised: solution } \\
\text { focused approaches will let you create situations to lower } \\
\text { your workload" (Quebec, 88-91) }\end{array}$ \\
\hline & $\begin{array}{l}\text { Dealing with Novel Stressors } \\
\text { (25\%) } \\
\text { Type: Semantic }\end{array}$ & $\begin{array}{c}\text { "Sometimes you get to that point where like everything } \\
\text { ahh cant really phase you anymore, you've basically quite } \\
\text { literally seen everything that can affect you. } \\
\text { You know, but sometimes god loves throwing you a } \\
\text { curveball making you feel as lost as the day you started" } \\
\text { (Juliet, 107-116) }\end{array}$ \\
\hline & $\begin{array}{l}\text { Job Autonomy (24\%) } \\
\text { Type: Latent }\end{array}$ & $\begin{array}{c}\text { "I'm at the top of my directive in the company globally. } \\
\text { After I got my doctorate the amount of responsibility and } \\
\text { freedom I got to do the job was insane. } \\
\text { I cant cant deny my freedom allows me to deal with the } \\
\text { challenges our company faces" (Hotel, 31-40) }\end{array}$ \\
\hline \multirow[t]{2}{*}{$\begin{array}{r}\text { Synergy } \\
(25 \%)\end{array}$} & $\begin{array}{l}\text { Peer Support (73\%) } \\
\text { Type: Latent }\end{array}$ & $\begin{array}{c}\text { "I would describe the team as a really really good team, } \\
\text { who get on very very well, very open, very transparent, } \\
\text { and I often ask for feedback" (Bravo, 73-74) }\end{array}$ \\
\hline & $\begin{array}{l}\text { Job Identity (27\%) } \\
\text { Type: Semantic }\end{array}$ & $\begin{array}{l}\text { "It's a struggle but it's more rewarding to be contributing } \\
\text { to the public good than it is to save (Company) a bit of } \\
\text { money. It's more morally rewarding to do something } \\
\text { good than be good at something. That's a fundamental } \\
\text { difference for me." (Charlie, 180-182) }\end{array}$ \\
\hline \multirow[t]{2}{*}{$\begin{array}{c}\text { Work/Life Balance } \\
\text { (9\%) }\end{array}$} & $\begin{array}{l}\text { Overburden (52\%) } \\
\text { Type: Latent }\end{array}$ & $\begin{array}{c}\text { "I think (Company) moves incredibly fast, it's too fast } \\
\text { sometimes, it's very very difficult to stay on the forward } \\
\text { edge of it." } \\
\text { (Alpha, 62-63) }\end{array}$ \\
\hline & $\begin{array}{c}\text { Erosion of Social Support } \\
\text { (48\%) } \\
\text { Type: Semantic }\end{array}$ & $\begin{array}{l}\text { "Well I'm single and I find that one of the big impacts, } \\
\text { If anyone asks me to do anything privately I really } \\
\text { struggle to find time even on a weekend" } \\
\text { I'm pretty much here, if I'm not working on something } \\
\text { even on weekends as well" } \\
\text { (Echo, 67-69) }\end{array}$ \\
\hline
\end{tabular}




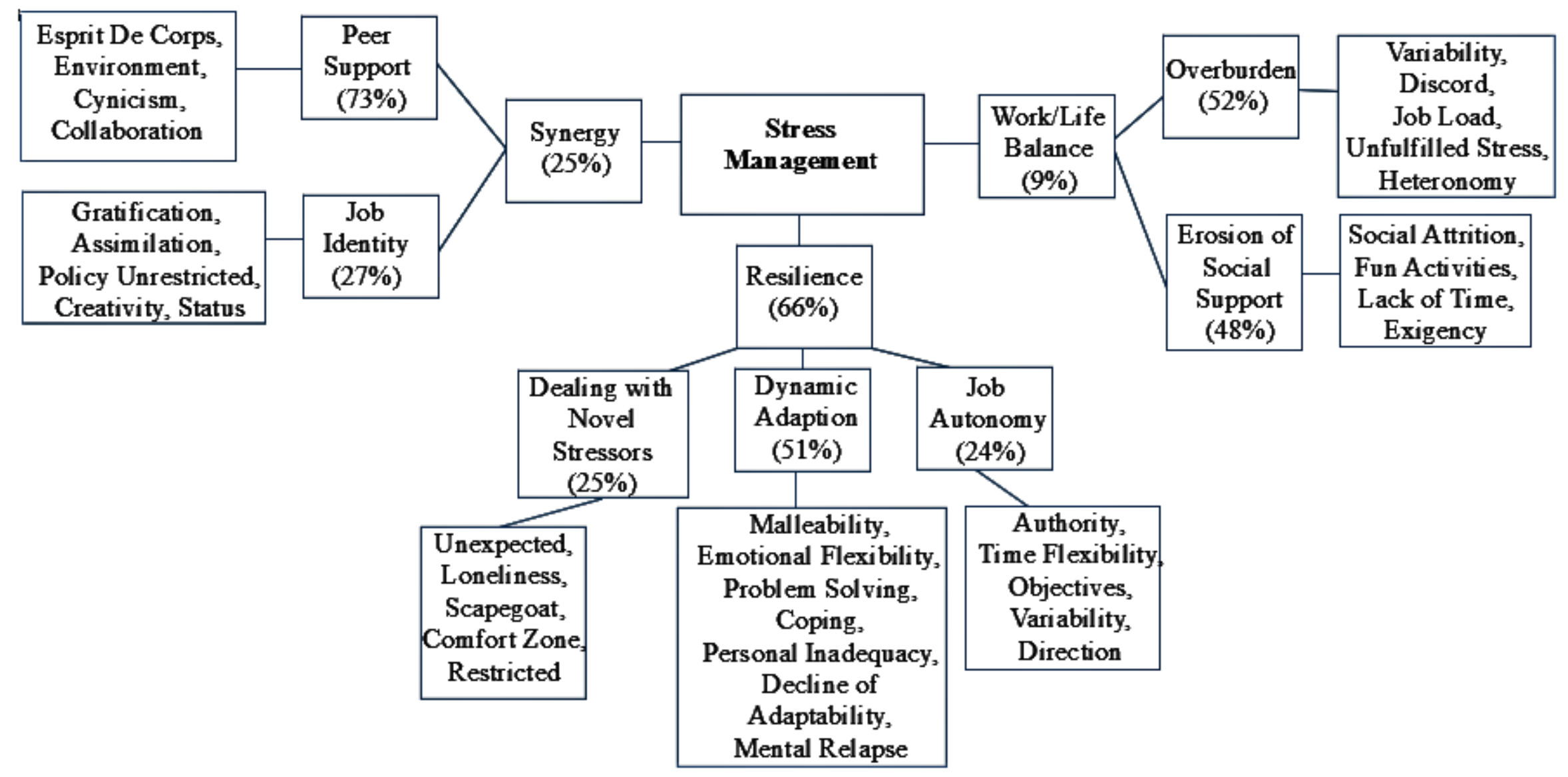

Figure 1: Themes of Stress Management 